Mannion, G. \& Lynch, J. (2016) The primacy of place in education in outdoor settings. In Barbara Humberstone, Heather Prince, Karla A. Henderson (Eds) International Handbook of Outdoor Studies. Routledge (pp 85-94).

\title{
The Primacy of Place in Education in Outdoor Settings
}

Greg Mannion, School of Education, University of Stirling

Jonathan Lynch, University of Cumbria

In this chapter, we explore and support the call for greater attention to be paid to place in outdoor education. We consider this call to have particular relevance since education in the outdoors can work as an antidote to what some have described as a sense of de-placement (Orr 1994) as inhabitants of local places that are globally connected. Casey, analyst and interpreter of the deep history of philosophical perspectives on place, provides a starting point for our understanding of how, as educators, we might usefully take more account of place as an event that is always 'newly emergent' and radically heterogeneous (Casey, 1998).

Our main argument is that place has begun to, and needs to further '(re-)appear' as a primary eventful feature of our understanding of our life in the world but that we need to push further to theorise and understand how in education in outdoor settings. We seek to theorise and suggest ways for how we might more sensitively plan and enact place-responsive outdoor education. We hope our contributions will have relevance for the fields of outdoor education (in formal or non-formal curricula) in outdoor experiential learning, adventure education, fieldwork, and other forms of provision in education settings (such as outdoor play in early years) or in local areas (for example in forest, beach, or urban settings). 


\section{The re-appearance of place in outdoor education}

Across all disciplines and across theory and practice, place has emerged in recent years as a core concern but it remains curiously less well connected to the literature on outdoor education. In the long tradition of outdoor education (Ogilvie, 2013), there have, of course, been varied commentaries on place through few comprehensive theoretical treatments. Historical and socio-cultural readings (Humberstone, Brown, \& Richards, 2003) encourage us to notice the way outdoor education's purposes have changed within its wider sociopolitical landscape. Over time as purposes have changed, 'place' has been colonised, harnessed, reinvented, and renamed (as, for example, the 'outdoor gym', 'threatened environment', or the 'great outdoors'). Purposes such as "fitness for war", "character building", "social education", "recuperative holiday for socially disadvantaged young people", and "progressive education" are all identifiable (Nicol 2002) within a sustained emphasis on psycho-social outcomes.

In the last fifty years, with the rise in concern for environmental issues, experience in nature has gained renewed significance. For example, Mortlock (1989) posited that outdoor education could be conceptualised as contributing to the development of "an awareness of, respect for, and love of self...others... and the environment" (1989, p. 18). Links across the ‘character building', pursuits/adventure, and environmental traditions became more explicit in the 1990s (Higgins \& Loynes 1997). Higgins (2002) comments that there are three emphases in the field of outdoor education: (i) environmental education, (ii) personal and social development, and (iii) outdoor activities. Whilst any education in outdoor settings could be concerned at any one time with all three of these aspects, at times many provisions appear to ignore the more person-place, relational outcomes of the environmental education emphasis. Reasons given for this failure to take account of place we suggest come from over- 
emphasis on the other two dimensions. The first over-emphasis (on personal and social development) can be built on the use of humanistic, experiential approaches that privilege the cognitive reflective process (wherein outdoor education is a 'method'); the other overemphasis comes when the activity is all embracing (where this is outdoor education's 'content') (see Quay and Seamon, 2013). Quay and Seamon (2013, p. 38) overcome this dyadic emphasis - that we suggest may each ignore place - through their revisiting of an older definition of outdoor education being "education in, about and for the outdoors" (Donaldson and Donaldson, 1958). Quay and Seamon (ibid, p. 93), using Dewey, see these three aspects ('in', 'for' and 'about') as having equal importance, working together connecting people, place and activity. Quay and Seamon call for outdoor educators to ask: "what ways of being a person centrally involves the outdoors, and what does it take to knowledgably participate in these activities?” (2013, p. 78).

There are many now long-standing arguments about how some approaches to outdoor adventure and personal development have been privileged at the expense of nature and people's relationship with community and place (Brown, 2012; Brookes, 2003a; 2003b; Loynes, 1998; Beames 2006). There is some empirical work in this area that provides sustained support for a more relational position both in theory and practice concerning place. In Mannion, Sankey, Doyle, Mattu \& Wilson's (2006) study, which looked at the narratives of young people's accounts of valued outdoor experiences, the categories of 'place', 'activity', and 'interpersonal' were found to be always intimately connected in any person's account of a valued outdoor event, pointing to the need to make curricula with place in mind, in ways that too carry these three interdependencies into experiences and learning. In recent years, a number of commentators do indeed appear to be 'getting back into place', as Casey 
might put it (see Brookes, 2002; Brown, 2012; Quay and Seaman 2013; Stewart, 2008) and we turn to look at some of these next.

\section{Theoretical Orientations to Place in Outdoor Education}

Roberts (2011) identifies five 'currents' in experiential education (which is closely allied to outdoor education). These are: Romanticism, Pragmatism, Critical Theory, and Market Rationality (Roberts 2011). Extending, and at the same time converging some of the analysis of Robert's here, we describe how place gets treated in the following three traditions: Sociohistorical and critical, (post-)phenomenological and pragmatic, and socio-ecological.

\section{The socio-historical and critical traditions}

Some researchers take an explicitly socio-cultural reading of outdoor education. Waite and Pratt (2011), for example, explore how learning opportunities emerge through relations between child, others and place, making a relational reading of person-place interaction the core concern. In the critical tradition, place-based education has brought a significant set of resources for outdoor education to draw upon. As a field, place-based education is concerned with facilitating meaningful relationships with places, noteworthy discourses include those that focus on anti-globalisation and a desire to rebalance the importance of relationships in education through attention to community and place (Gruenewald, 2003, 2008; Gruenewald and Smith, 2008). Importantly, for our developing argument, Gruenewald (2008) differentiates place from community but argues that place-based education is nonanthropocentric and includes the nonhuman world. Finally, we note that Tuck, McKensie \& McCoy (2014) show land education as emerging as a response to the concerns of political neutrality in place-based education in terms of land history and colonisation. They place 
indigenous epistemologies and ontologies at the centre and challenge colonial influences in education.

The (post-)phenomenological and pragmatic traditions

Another strand of writing in this renewed attention to place comes through employing phenomenology and pragmatism as a linked lens (Quay 2013, Stewart 2004, 2008, Wattchow and Brown 2011). Quay (2013) provides a more nuanced view of how pragmatism (after Dewey) and phenomenology (after Heidegger) suggest in subtly different ways that self, other, and nature need to be understood as connected via aesthetic activity (or 'occupation', after Dewey). Stewart employs a phenomenology of travel through place (with his tertiary education students). Wattchow and Brown's (2011) work on pedagogy and place in outdoor education takes a look at the experiences and dispositions of experienced expert outdoor educators vis place in their work to make a similar set of arguments.

What is of note too is how many authors seek to bring together more than one perspective in the shift towards place-sensitivity. Stewart (2008) takes the cultural, ecological and historical reading of landscape as a linked but core task. Brookes (2003b) sees the development of relationships between individuals, groups and places in particular 'situations' outdoors. Somerville, takes a more poststructural approach. She sees places as co-created through teachers' and learners' subjectivity: for her place is relationally pedagogical (Somerville, 2008; 2009). These contributions in quite different ways can be seen as responses to a shared goal: a desire to move the field towards a recognition of the importance of place as changing, as relational, as cultural and social, as human and more-than-human, as aesthetic and focus for reflection, as experienced through embodiment, yet arising with its own agencies. 
Taken together, we see possibilities for a post-phenomenological (see Payne 2003) orientation to outdoor education as viable. We believe taking outdoor education as occurring in a place-based event in ways that take the physical location as more than container can help us frame and understand the on-going convergence of inner and outer worlds. Postphenomenological approaches would look to take place as a primary frame for an outdoor education that seeks to enhance person-place relations: "it is, indeed, in and through place that the world presents itself" (Malpas, 2008,p. 15). The result of this kind of framing is a renewed attention to embodied and aesthetic experience of place as well as reflective practice. Doing both seems necessary for place-responsive teaching outdoors - but it may not be sufficient for a fully place-responsive approach.

\section{$\underline{\text { Socio-ecological approaches }}$}

Emerging theorising on place and place-based education is also helpful in recognising the ontological significance of the more-than-human and the importance of a relational view of the social and the ecological (Wattchow et al, 2013). We identify Somerville too as an example of a place-based educator with a strong socio-ecological sensitivity. Her work is based on an understanding that place is co-created and relationally emergent. She posits that our relationship to place is constituted in stories and other representations: place learning is embodied and local and it's a contact zone of cultural contestation $(2009$, p. 8). Somerville developed a 'place pedagogies' approach (Somerville, 2008) which emerged from the ways we learn about place and from community. Place pedagogies include a focus on Story, Body and Contact Zone; noting that our relationship to place and community is constituted in our stories, place learning is embodied and local, and learning place and forming community is a contact zone of contested stories. 
Place and place-responsiveness both feature within the socio-ecological approach advocated by Hill (2012) which he sees as a framework that embraces diverse approaches to education which can meet the needs of individuals, communities, ecosystems and environments. McKenzie et al (2013) have noted that a socio-ecological pedagogy sees learning occurring relationally and involves being in places, being reflective, being creative, and engaging with communities. Taking a socio-ecological approach strongly re-asserts the lived, embodied, everyday aspects of pedagogy with and in place such that we can generate viable responses. But there is a risk of overly resting on phenomenological hermeneutics or humanistic poststructural socio-critical traditions which may bring too much of a commitment to decontextualised anthropocentric perspectives or ends focused on the human. In response, we ask, in what ways can place-responsiveness be a reciprocal eco-social process involving humans and other entities?

\section{Place-Responsiveness and Outdoor Educational Provisions}

Casey's (1998) general thesis is that the term and idea of 'place' fell from discussions in theology and physics over time to be replaced by the idea of abstract, absolute, homogeneous, Euclidean and infinite space or container (for example, with the use of the term 'universe' as against 'cosmos'). Only, later, did the idea of place-as-event emerge as considerations of how time and embodied experience were taken on board as relevant to our understandings of life in the world. For our purposes, then we take learning in outdoors as always emplaced. Here, any given place is at once local, regional and global, intimate and infinite, limited and delimited for "place itself is everywhere" (Casey, 1998, p. 305). Starting with Casey’s ideas, we set out below some of the features of a place-responsive outdoor education. 
Cameron (2003) offers the useful term 'place-responsiveness' now being picked up in the outdoor studies field. He notes:

Place is not the mere passive recipient of whatever humans decide they wish to do upon the face of it. The land is an active participant in a very physical sense...it [sense of place] includes a growing sense of what the place demands of us in our attitudes and actions. (ibid, 176)

For Cameron, place includes the more-than-human and we need to respond both to others, to the place via other stories of place (ibid, 194). Wattchow and Brown (2011) take up the term place-responsive pedagogy (after Cameron, 2003) as challenging the trend of placeless curriculum making within globalisation. They seek ways to operationalize placeresponsiveness in outdoor education suggesting four signposts:

1. Being present in and with a place.

2. The power of place based stories and narratives.

3. Apprenticing ourselves to outdoor places.

4. The Representation of place experiences. (Wattchow and Brown, 2011, p. 182).

Wattchow and Brown (2011) and Somerville (2008) put forth appealing and strong arguments that move us towards a place-responsive pedagogy based in part on the work on story. But if by 'stories' we mean human meaning making and solely representations of human lived experience, then we worry place may get lost in the subjective story situated in the human life-world. We feel we should seek other framings of meaning making that are less reliant on humanist registers to open up pedagogical considerations of place that allow a broadening of the ontological significance of what is found outdoors. 
Mannion, Fenwick and Lynch (2013) incorporate some of the influences of the emerging writing in place and post-structuralism to nuance what they mean by responding to place. They base a place-responsive approach on the view that people and places are relationally emergent. They suggest responding to place involves reciprocity and involves explicitly teaching by-means-of-an-environment with the aim of understanding and improving humanenvironment relations. Their approach is more focussed on linking purposes with an emergent ontology of place wherein stories reside. Here, learners, places, stories and all kinds of entities are intermingling with and educationally relevant: all the material aspects of a place (stones, water, air) and the more-than-human (grass, trees, animals etc) can have a 'say'. Their approach seeks to move beyond the binary of person and place, indoor vs outdoors to eke out the pedagogical potential of place from a view that understands the world is in formation. For Mannion, et al. (2013) this is a question of accepting a relational ontology of place-as-event as always given - we are always inside place events.

Similarly, Mannion and Gilbert (forthcoming) posit that people and places are relationally emergent through the activities of both people and many other entities and processes that allow life to unfold (including the weather, the activities of animals as much as humans). After Ingold (2011) agency no longer 'resides' in one location or in the human; it proceeds dynamically along connective tissue which allows for the enactment of a relationship; within these interpenetrating socio-material relations, people and place co-emerge. In the project, Stories in the Land, Mannion and Gilbert (forthcoming) used narrative approaches to explore the role of story for children, their local communities in ways that connected to local landscapes. This contextualized approach counters a view of literacy as a decontextualised and portable skill that cuts across any context and can be learned in a formulaic way. Instead, we suggest we take seriously Somerville's idea that narratives, identities and experience are 
deeply connected and shaped by practices in particular places. We encouraged story making as a practice alongside the lived experiences of journey and place: these are the necessary coingredients in outdoor education (see Anderson 2004).

Working with similar ideas but applying them to curriculum making, Ross and Mannion (2012) foreground the entanglement of people-place relations that are re-made through relationships between them. Importantly, they deny that solely cognitive representations of these experiences are either possible or necessary: "The curriculum making here is not the manipulation of symbols or representations of environment. It is the manipulation of the constant, active engagement with the environment in which teachers and learners are both entangled and which both produce" (ibid, p.14). We are immersed in the world, not separate from it and hence, learning need not be overly reliant on decontextualised representations or symbols. They suggest the world becomes meaningful for its inhabitants through active socio-material inhabitation and which involves something other than mere cognitive representation. We become in an entangled or interlaced manner in relation to other species and the environment as 'points of growth'.

To summarise then, we argue that place-responsive outdoor education involves three aspects: (a) attending to the subjective, personal development and 'inner world' of experience of place (see for example, Higgins and Wattchow, 2013), (b) without losing sight of the need to learn an activity itself- we need to attend to the aesthetic practice-oriented ways of being (or Dewey's 'occupations') (see Quay 2013), yet (c) all the while, attending to the need to attune to the place-based, more-than-human, living and inanimate materials that are also active as agencies in curriculum making (see Rautio 2013) whether these be local or further flung. 
We warrant that place responsiveness as an idea in outdoor education that now has significant implications for its planning and enactment. Our following guidelines for practice seek to provide some possible ways of taking these implications on board.

\section{Planning with Place: A typology}

Mannion et al (2011) drew on analysis of empirical examples to derive a heuristic tool for addressing place in the planning of outdoor education. Their analysis of teachers lived experiences of teaching in outdoor settings generated a typology of dispositions to planning for outdoor learning. These ‘types' are best considered as not completely distinct from each other but exist on a continuum of place-responsiveness:

1. Place-ambivalent teaching strategies do not actively plan to take much account of the place as a contributing factor in teaching and learning.

2. Place-sensitive teaching strategies do plan to take some active account of the role the place will play in teaching and learning.

3. Place-essential teaching strategies are planned so that they cannot be enacted if some specific location is not available for teaching and learning.

For Mannion et al (2011), planning in a 'place-ambivalent' way means setting out to do a lesson that is almost completely transportable to any setting regardless of place-based contingencies such as time of day, season, weather, terrain, presence of other species, possibilities for encounters with local people and so on. We have all seen times when teachers literally seek to bring a given lesson they would normally have done indoors to an outdoor place - perhaps because it is a warm day - bringing tables and chairs with them on occasion. In place-ambivalent planning, educators seek to reproduce or 'export' a teaching strategy from one place (perhaps indoors) into a new outdoor setting without actively taking much account of the affordances the place has on offer. 
A further example of its use might help us explore what we mean here. In place-ambivalent planning, an educator might sets out to educate about the ecological significance of light as a source of energy; to do the lesson, s/he may decide to take a lab experiment on plants in pots outdoors into the school grounds. Here, materials from indoors are brought outdoors as part of a replication of teaching approaches enacted in another indoor place.

In place-sensitive planning, an educator may indicate to the learners that the nearby woodland is a place with mixed species woodland where there are various canopy densities, (and various light intensities) and thus various levels of plant growth. Here, many alternative outdoor places with trees might therefore afford opportunities for such a lesson.

Planning education in outdoor settings as place-essential would mean that a specific place be relevant through what it can pedagogically offer, in other words, what will relationally emerge there. In a 'place-essential' approach, planning starts with the emerging place-asevent and considers how and what forms of curriculum making might be possible within and through that set of processes. Hence, to consider our case example again, in a particular woodland, the educator, mindful that meaning will relationally emerge, might notice that the learners are noticing varying light intensity and that that could be part of the learning experience on a given sunny day in a given part of the woodland. In addition, they might consider the new understandings around light and plant growth as part of a wider framing of place relations: whose land it is, what species were planted there / were native / invasive, and what on-going local practices of woodland management were on-going or perhaps needing to be engaged in as a result. This is a departure from the established rational-linear models of planning where learning objectives are set beforehand and drive the planning process and where place is not factored as important in the planning other than as an container. 
As Mannion et al. (2013) have found, taking a place-essential approach will mean educators are likely to benefit from knowing well the places where the teaching and learning experiences are to be enacted or knowing in some depth the kinds of things that are likely to happen in the place visited. Aside from planning in a place-responsive way, teachers also need to take a responsive attitude to the educational encounter in an on-going manner which may involve a degree of contingency.

In seeking to advance these kinds of adaptations to enacting teaching as much as in the planning, we have devised the following manifesto for place-responsive practice based on our arguments and discussions above. We have found this to be a useful text for prompting teachers (in-service and pre-service) to consider when and how place is harnessed explicitly into their teaching:

\section{A Manifesto for Place-Responsive Teaching}

In my teaching ...

1. I strive to gain an in-depth knowledge of places to inform what I do as an educator.

2. I strive to help learners respond to places:

a. Before, during and after educational excursions to places, I strive to help learners gain an understanding and appreciation of places and what is distinctive about them.

b. When appropriate, I bring learners back to the same or similar place to enable a greater depth of response to place.

c. I strive to get learners to make responses to place that are embodied, cognitive, emotional, aesthetic and ethical.

d. I actively invite learners to respond to selected happenstance, contingent, and unforeseen events encountered in places.

3. I strive to harness the distinctiveness of places in my teaching...

a. Whether indoors or outside, I facilitate learning in ways that could not be easily replicated in a different place.

b. When teaching outdoors, I facilitate learning in ways that could not be easily replicated in a different outdoor location.

4. I invite learners to make their own efforts to create viable and more sustainable responses to place in ways that advances environmental and social justice and equity in their own lives and the lives of others. 
The manifesto is suggestive of the need for openness to encounters with place-differences that take us beyond ourselves. Happenstance encounters and experiences - for example with a woodland owner, the sounds, smells and feelings emerging for participants when the sun shines on the leaves and on their cheeks - these might all need to be harnessed into the learning. Much of this will be unknown and unplanned at the outset. In place-responsive outdoor education, meanings will come about through the acceptance of knowledge emerging through the on-going entanglement of people / place / the-more-than-human. And these entanglements are present whether we are experiencing a place, reflecting on it or transforming it on our own or with others.

\section{Conclusion}

We might have expected that place would never have needed to re-appear as a central concern since the location of such learning one would expect has always been clearly consequential. But critiques of the field of practice have noted that place has often been ignored in outdoor education and its role has not only been unclear but has been under theorised and quite contested. We have shown when and how 'place' is being reasserted as a key unifying concern that makes outdoor pedagogy viable, meaningful, and worthwhile. This has taken many forms especially in outdoor education and outdoor learning since places themselves are so diverse as are our relations with them. This interest in place, although not new, seems now to be reasserted in response to dominant approaches that have overly privileged cognitive and reflective processes. The reassertion of place asks us to take greater account of the eco-social, material place, to consider the purposes of programmes in these places, and the links between local and global places. We have also presented sources that 
help us understand how people, place, and the more-than-human are relationally-emergent in curriculum planning and the enactment and transformation of outdoor curriculum making.

The contribution we hope to make with this chapter is to help mp out and reposition a concern with place as part of a wider agenda within education as attending in material and embodied ways to differences that arise ... noticing that these differences are always in a place. These can be more easily understood as necessary once (or if) educators take on board the ontological disposition where people and place are always entangled in on-going events that are reciprocal in nature. Within a reciprocal ontology of becoming, learning is always situated and is an on-going happening and, therefore, could be said to always be locally 'performed' as a result of the responses people make within a particular person-place assemblage or enmeshment (see Ingold 2011). Learning is influenced by what people do in and to a place and how places act back on them over time. Educationally, there is a need to plan for place-responsiveness and in the moment notice these person-place experiences harnessing them into the pedagogy in more responsive ways. Working more pro-actively to make curriculum making more place-responsive takes us back to the keynote idea by Casey in the introduction: place is pedagogically emergent and more than a cultural or historical 'container'. At a time when the planet faces diverse ecological and social challenges, given that place and meaning emerge in our co-extensive encounters with it, we think that the provision of education in outdoor settings can be planned and enacted more effectively when it does so with place in mind.

\section{References}

Anderson, J. (2004). Talking whilst walking: a geographical archeology of knowledge. Area, 36(3): 254-61.

Beames, S. (2006). Losing my religion: The struggle to find applicable theory. Pathways: The Ontario Journal of Outdoor Education 19(1), 4-11. 
Brookes, A. (2002). Lost in the Australian bush: Outdoor education as curriculum. Journal of Curriculum Studies 34(4), 405-425.

Brookes, A. (2003a). A critique of neo-Hahnian outdoor education theory. Part one: challenges to the concept of 'character building'. Journal of Adventure Education and Outdoor Learning 3(1), 49 - 62.

Brookes, A. (2003b). A critique of neo-Hahnian outdoor education theory. Part two: 'the fundamental attribution error' in contemporary outdoor education discourse. Journal of Adventure Education and Outdoor Learning 3(2), 119-132.

Brown, M. (2012). Student perspectives of a place-responsive outdoor education programme. New Zealand Journal of Outdoor Education 3(1), 64-88.

Brown, T., Jeanes, R. \& Amy Cutter-Mackenize. (2014). Social Ecology as Education. In B. Wattchow, R. Jeanes, L. Alfrey, T. Brown, A. Cutter-Mackensie, and J. O'Conner (Eds.), The Socioecological educator (pp. 23-46). London: Springer.

Cameron, J. (2003). Responding to place in a post-colonial era: An Australian Perspective. In W. Adams, and M. Mulligan (Eds.), Decolonising nature: strategies for conservation in a post-colonial era (pp. 172-197). London: Earthscan.

Casey, E. (1998). The fate of place: A philosophical History. London: University of California Press.

Donaldson, G., \& Donaldson, L. (1958). Outdoor education: A definition. Journal of Physical Education, Recreation \& Dance 29(17), 17 and 63.

Gruenewald, D. \& Smith, G. (2008). Place-based education in the global age. Abingdon: Taylor and Francis.

Gruenewald, D. (2008). Place-based education: Grounding culturally responsive teaching in geographical diversity. In D. Gruenewald, and G. Smith, (Eds.), Place-based education in the global age (pp.137-154). Adingdon: Taylor and Francis

Gruenewald, D. (2003). The best of both worlds: A critical pedagogy of place. Educational Researcher 32(4), 3-12.

Higgins, P. \& Loynes, C. (1997). Towards consensus on the nature of outdoor education. Journal of Adventure Education and Outdoor Leadership 15(1), 5-9.

Higgins, P. (2002). Outdoor Education in Scotland. Journal of Adventure and Outdoor Learning 2(2), 149-168.

Higgins, P. \& Wattchow, B. (2013). The water of life: creative non-fiction and lived experience on an interdisciplinary canoe journey on Scotland's River Spey. Journal of Adventure Education \& Outdoor Learning 13, 13-18. 
Hill, A. (2012). Introducing a critical socio-ecological approach for educating outdoors. In D. Irwin, J. Stracker and A. Hill, (Eds.), Outdoor education in Aotearoa New Zealand: A vision for the 21st Centaury (pp. 46-64). Christchurch New Zealand: CIPT.

Humberstone, B., Brown, H. \& Richards, K. (2003). Whose Journeys?

The Outdoors and Adventure as Social and Cultural Phenomena. Barrow-in-Furness: Fingerprints.

Ingold, T. (2011). Being Alive; essays on movement, knowledge and description. Oxon: Routeledge.

Loynes, C. (1998). Adventure in a bun. Journal of Experiential Education May/June 21, 3539.

McKenzie, M., Butcher, K. Fruson, D., Knorr, M., Stone, J., Allen, S., Hill, T., Murphy, J., McLean, S., Kayira, J. \& Anderson, V. (2013). Suited: Relational Learning and Socioecological Pedagogies. In R. Stevenson, M. Brody, J. Dillon and A. Wals (Eds.), International Handbook of Research on Environmental Education (pp. 487-498). London: Routeledge.

Malpas, J. (2008). Disclosing the depths of Heidegger's Topology: A response to Relph. Environmental and Architectural Phenomenology 19(1), 9-12.

Mannion, G., Sankey, K., Doyle, L., Mattu, L.\& Wilson, M. (2006). Young people's interaction with natural heritage through outdoor learning. Scottish Natural Heritage Commissioned Report No. 225. University of Stirling. Accessed from: http://www.snh.gov.uk/publications-data-and-research/publications/search-thecatalogue/publication-detail/?id=877 [Last accessed May 2014]

Mannion, G., Fenwick, A., Nugent, C. \& I'Anson, J. (2011). Teaching in Nature. Report Contracted to University of Stirling, Commissioned by Scottish Natural Heritage.

Mannion, G., Fenwick, A. \& Lynch, J. (2013). Place-responsive pedagogy: learning from teachers' experiences of excursions in nature. Environmental Education Research 19(6), 792-809.

Mannion, G. and Gilbert, J. (forthcoming). Place-responsive Intergenerational Education. In R. Vanderbeck and N. Worth (Eds) Intergenerational Space. London: Routledge.

Mortlock, C. (1989). The Adventure Alternative. Milnthorpe: Cicerone Press

Nicol, R. (2002). Outdoor education: Research topic or universal value? Part one. Journal of Adventure Education \& Outdoor Learning 2(1), 29-41.

Ogilvie, K. (2013). Roots and wings: A history of outdoor education and outdoor learning in the UK. Dorset: Russell House Publishing.

Orr, D. (1994). Earth in mind: on education, environment, and the human prospect. Washington, DC: Island Press. 
Payne, P. (2003). Post-phenomenological enquiry and living the environmental condition. Canadian Journal of Environmental Education, 8, 169-190.

Plumwood, V. (2000). Belonging, naming and decolonization', Ecoplotics: Thought and action 1(1), 90-106.

Quay, J. (2013). More than relations between self, others and nature: outdoor education and aesthetic experience. Journal of Adventure Education \& Outdoor Learning 13:2, 142 157.

Quay, J. \& Seaman, J. (2013). John Dewey and Education Outdoors: Making Sense of the 'Educational Situation' through more than a Century of Progressive Reforms. Rotterdam: Sense Publishers.

Rautio, P. (2013). Being nature: interspecies articulation as a species- specific practice of relating to environment, Environmental Education Research, 19:4, 445-457.

Roberts, J. (2011). Beyond learning by doing: Theoretical currents in experiential education. New York: Routledge.

Ross, H. \& Mannion, G. (2012). Curriculum making as the enactment of dwelling in places. Studies in Philosophy and Education 31(3), 303-313.

Somerville, M. (2008). A Place Pedagogy for 'Global Contemporaneity'. Educational Philosophy and Theory 42 (3), 326-344.

Somerville, M. Power, K. \& Pheonix de Cartet. (2009). Landscapes and learning place studies for a global world. Monash University Australia: Sense publishers.

Stewart, A. (2008). Whose place, whose history? Outdoor environmental education pedagogy as 'reading' the landscape. Journal of Adventure Education and Outdoor Learning $8(2), 79-98$.

Stewart, A. (2004). Canoeing the Murray River (Australia) as Environmental Education: A tale of two rivers. Canadian Journal of Environmental Education 9, 136-148.

Tuck, E., McKenzie, M. \& McCoy, M. (2014). Land education: Indigenous, post-colonial, and decolonizing perspectives on place and environmental education research. Environmental Education Research 20(1), 1-23.

Waite, S. \& Pratt, N. (2011). Theoretical perspectives on learning outside the classroom: relationships between learning and place. In S. Waite (Ed.), Children Learning Outside the Classroom: from birth to eleven (Pp. 1-18).London: Sage.

Wattchow, B. \& Brown, M. (2011). A Pedagogy of Place. Clayton: Monash University Publishing.

Wattchow, B., Brown, T., Jeanes, R., O'Conner, J., Cutter-Makenzie, A. \& Alfrey, L. (2014) Conclusions and Future Directions: A Socio-ecological Renewal. In B. 
Wattchow, R. Jeanes, L. Alfrey, T. Brown, A. Cutter-Mackenzie (Eds.), The

Socioecological Educator (pp. 205-228). London: Springer.

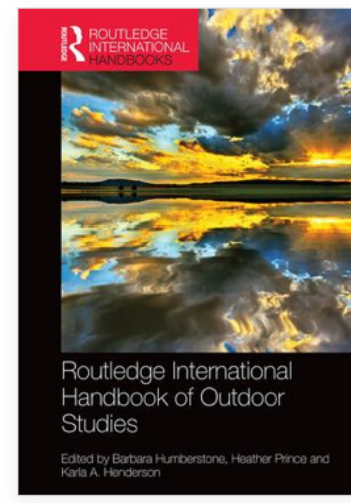

\section{Routledge International Handbook of Outdoor} Studies

Edited by Barbara Humberstone, Heather Prince, Karla A. Henderson

() 2016 - Routledge

530 pages

Q. Look Inside

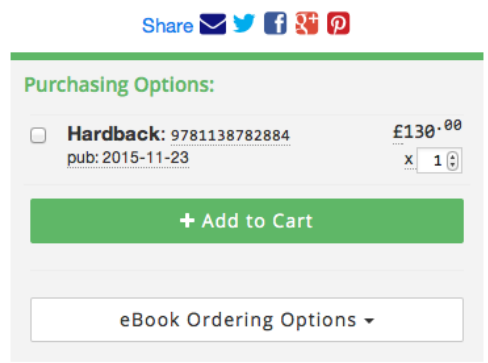

Description Contents Editors Series Subjects

About the Book

The 'outdoors' is a physical and ideological space in which people engage with their environment, but it is also an important vehicle for learning and for leisure. The Routledge Handbook of Outdoor Studies is the first book to attempt to define and survey the multi-disciplinary set of approaches that constitute the broad field of outdoor studies, including outdoor recreation, outdoor education, adventure education, environmental studies, physical culture studies and leisure studies. It reflects upon the often haphazard development of outdoor studies as a discipline, critically assesses current knowledge in outdoor studies, and identifies further opportunities for future research in this area.

With a broader sweep than any other book yet published on the topic, this handbook traces the philosophical and conceptual contours of the discipline, as well as exploring key contemporary topics and debates, and identifying important issues in education and professional practice. It examines the cultural, social and political contexts in which people experience the outdoors, including perspectives on outdoor studies from a wide range of countries, providing the perfect foundation for any student, researcher, educator or outdoors practitioner looking to deepen their professional knowledge of the outdoors and our engagement with the world around us.

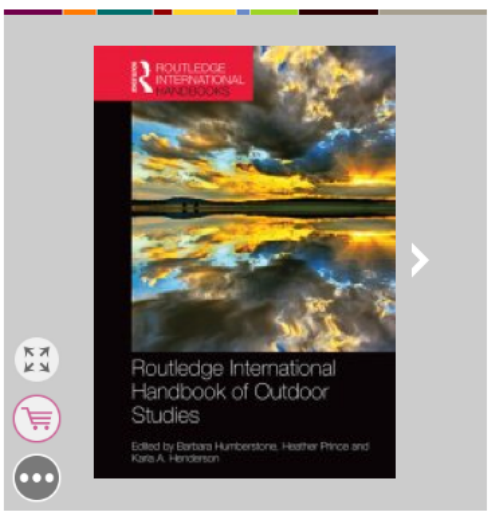

